\title{
TOPICS TOPICS TOPICS TOPICS TOPICS TOPICS TOPICS TOPICS TOPICS TOPICS
}

\section{Heavy-Drinker における 抗エイズ薬の体内動態}

\section{京都薬科大学薬物動態学 \\ 芝田 信人}

\section{はじめに}

酒類に含まれるエタノールは，薬物代謝においてさまざ まな相互作用をもたらすことが知られている。急性のアル コール摂取は，NADPH 系薬物代謝酵素が阻害され，抗 血栓薬や睡眠薬の血中濃度が上昇する。一方，慢性的なア ルコール摂取は代謝酵素，チトクローム P450 (CYP) 2E1 を誘導することは周知で，この代謝酵素を介した薬物の 消失は加速される．また，エ夕ノールは脂溶性薬物の可溶 化を促進するので，小腸からの吸収を高める場合がある. このように，薬物と酒類に含まれるエ夕ノールとの相互作 用では，CYP2E1 を介する代謝や薬物の物理化学的ある いは薬理学的性質に起因する相互作用として認知されてい る。一方, CYP3A4 は代謝関連藏器において多量に存在 する代謝酵素であり，現在上市されている薬物の約 $60 \%$ が CYP3A4 で代謝される薬物であるにもかかわらず，工 タノールとの相互作用に関する情報については乏しいとい える。

\section{アルコール㩒取時の saquinavir 体内動態}

IHV 感染症治療で汎用される HIV プロテアーゼ阻害薬 (PI，Table）は，すべて CYP3A4 を介する代謝を受け， 同じくCYP3A4 を介して代謝される薬物の併用により相 互作用を誘発する可能性がある。一般論として，薬を服薬 中にアルコールを摂取することは避けるべきとされるが， アルコール摂取時の PI の体内動態に関する情報は, 添付 文書やインタビューフォームなどの一次資料には記載され ていない、筆者は HIV 感染症患者を対象とした血中 PI 濃度測定(TDM)を通じて， saquinavir と ritonavirによ るデュアルプロテアーゼにより治療されている患者で，飲

Table 臨床で使用されている HIV プロテアーゼ阻害薬 (PI)

\begin{tabular}{ll}
\hline \multicolumn{1}{c}{ 一般名 } & \multicolumn{1}{c}{ 商品名 } \\
\hline ritonavir & ノービア \\
indinavir & クリキシバン \\
saquinavir & インビラーゼ，フォートベース \\
nelfinavir & ビラセプト \\
amprenavir & プローゼ \\
lopinavir/r & カレトラ (ritonavir との配合剂) \\
\hline
\end{tabular}

酒嗜好の患者群の血漿中 saquinavir 濃度がアルコールを 摂取しない患者群に比べて顕著に低下するという現象を経 験した (Fig. 1)。これら患者群のアルコール摄取量は, ビール瓶 3 本/day からウイスキーボトル 1 本/day と個人 差が認められたが，ritonavir と saquinavir によるデュア ルプロテアーゼ療法が施行されている期間中に，慢性的に アルコールを撽取している患者群であった。前述のよう に，アルコールは CYP2E1 を㧈もに誘導するので, CYP 3A4 を介して代謝を受けるPIの血漿中濃度が低下する原 因については不明な点が多い。そこで，この現象のメカニ ズムを調べるために，エ夕ノール摂取ラットを用いて saquinavir 経口投与後の体内動態を検討した ${ }^{11}$.ここで用い たエタノール摄取ラットは $15 \%$ エタノール水を自由摄取 させることにより作製したが，ヒトに換算した場合，ビー ルを $13 \mathrm{~L} /$ day 摂取した場合に相当する.Saquinavir を単 独で経口投与した場合，エタノール摂取日数依存的（最大 14 日）に血漿中 saquinavir 濃度-時間曲線下面積 (AUC) が減少し，その減少の程度は併用する ritonavir 投与量が多くなるほど顕著であった。また，反転腸管を用 いた saquinavir の取り込み実験では，14 日間，慢性的に エタノールを摂取させたラット㧍よび正常ラットの間で, 取り込み速度に有意な差は認められなかった。このことか ら，エ夕ノールを慢性的に摂取した場合の血漿中 saquinavir 濃度の顕著な低下は，少なくとも消化管粘膜の 透過性の低下によるものではないと考えられた。このよう に，モデル動物実験においてもエタノールの慢性摂取によ り， saquinavir 経口投与後のバイオアベイラビリティの 減少が確認されたわけであるが，このことは，結果的に PI による治療効果の減弱につながる可能性があることを 示唆している．筆者が経験した飲酒嗜好の患者群では，そ うでない患者群と同じ PI の用量で治療されていたにもか かわらず，免疫学的指標に有効性を示す結果は得られず， 結果的に ritonavir あるいは saquinavir の増量となった。

\section{飲酒と HIV 感染症治療}

PI を使用する highly active anti-retroviral therapy （HAART）で治療されている飲酒嗜好の HIV 感染症患 者を対象とした Shor-Posner らの臨床報告では，HIV ウ イルス量の減少率は飲酒しない患者に比べて約 $1 / 4$ である ことが明らかにされている21.また，アルコール摂取と HIV 感染症治療に関するKresina らの臨床報告では, HIV 感染症治療におけるアルコール摂取の問題は, HIV に関する基礎研究の進展と同様に治療効果を左右する重要 な課題と位置付けられている ${ }^{3)}$. 1 日当りコップ $4 ， 5$ 杯の アルコールの㧺取は，PI の治療効果の減弱をもたらすこ 


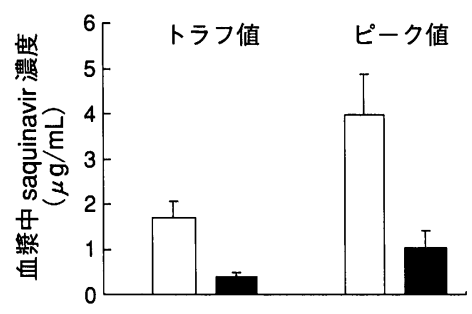

口飲酒樯好群 $(\mathrm{n}=3)$,

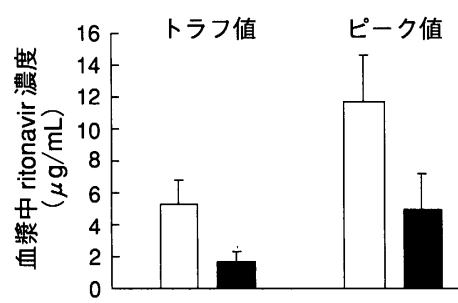

$\square$ 飲酒非嫱好群 $(n=4)$

Fig. 1 飲酒㖦好, 非㖺好で分類した場合の血漿中 PI 濃度の比較 ritonavir $800 \mathrm{mg} /$ day + saquinavir $800 \mathrm{mg} /$ day で治療開始. 採血は投与 が定常状態である時点で行った。

とはさることながら，HIVや HCV 感染による肝障害を 進行させると結論付けている．したがって，筆者が経験し たTDMの結果およびエタノール摂取ラットで認めた結 果を考慮すると，これらの臨床報告で認められた PI の効 果減弱は血漿中濃度の低下に起因しているものと考えら れ，PI 服薬中の慢性的なアルコール摄取は，薬剤のウイ ルス耐性を招来するリスクファクターと考えられる.

\section{エタノール摂取が saquinavir 体内動態に変動をもたらす要因}

アルコールがおもに関与する重要な代謝酵素は，アル コールデヒドロゲナーゼ，CYP 系酵素，グルタチオン-Sトランスフェラーゼである ${ }^{4)}$.そこで，先のエタノール摂 取ラットにおけるこれら酵素の saquinavir 体内動態への 関与を調べた。エタノールを 14 日間摂取させたラットか ら，肝抢よび小腸ミクロゾーム分画を調整し，NADPH 再生系のもと, saquinavir の代謝クリアランスを求めた ところ, 肝では変化がなく，エタノールの暴露が比較的大 きい小腸では代謝クリアランスが増大した。一方，エ夕 ノール摂取ラットでは肝および小腸可溶化分画中のグル夕 チオン-S-トランスフェラーゼ活性が有意に低下しており, saquinavir の代謝を促進する要因とはならないことが明 らかとなった。さらに，in-situ腸管ループ法を用いて CYP3A や腸管排泄トランスポータ，P-糖蛋白質 (P-gp) の関与を調べたところ, CYP3A よりも P-gp のほうがエ タノール摂取時に血漿中 saquinavir 濃度を低下させる要 因としてより強く関与していることを突き止めた。

\section{他の PI の体内動態にエタノール摂取が及ばす影響}

以上のように, saquinavir についてエタノール摄取時 の体内動態を述べてきたが，臨床では他の PI も使用され ており,アルコール摂取時の相互作用も当然予測される. Fig. 2 に示すように，エタノール摂取ラットに他のPI (indinavir, nelfinavir, amprenavir) を経口投与し, saquinavir の場合と同様に AUCを算出したところ, indinavir と nelfinavir の AUC は saquinavir と同様に低下 し, amprenavirのそれは逆に増加した。この結果は,

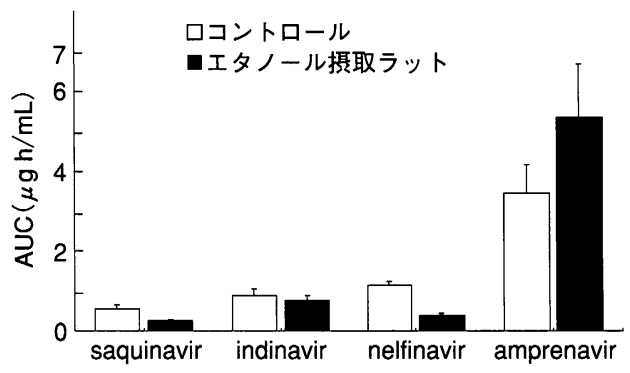

Fig. 2 各PIのAUCに及ほすエタノール摂取 (14 日間) の影響

各 PI $20 \mathrm{mg} / \mathrm{kg}$ の臨床用量で経口投与後, 経時的に 採血し, 血獎中 PI 濃度を LC/MS 法により測定した。

amprenavir の小腸吸収機構が一部他の PI と異なる可能 性を示唆しているが，詳細は今後の検討課題である。しか し，この事実は amprenavir の投与が他の PI とは異なり， 慢性的なエタノール摄取による血漿中濃度の低下をきたさ ないことを示している.

\section{おわりに}

近年の HAART 療法では，より強い抗ウイルス効果を 得るために，PI 2 剂併用する多剂併用療法が適応され つつある. 現在上市されている PI の代謝・排泄は，す心゙ て CYP3A4 や P-gp を介するため，併用時にはこれらを 介する相互作用が当然予期される。また，PI 2 剂の組み 合わせも多岐にわたるので，アルコール摂取時の相互作用 はさらに複雑なものとなろう。一方，HIV 感染症では， 多量のアルコール摄取や慢性的なその摄取が，その後の性 行動と付随して HIV 感染に多大に関連することが指摘さ れている，薬物治療では，服薬時のアルコール摂取は避け られるべきものであるが，PI を中心とした HAART 療法 開始後にも継続される飲酒嗜好は血漿中 PI 濃度の低下を きたし，アドヒアランスの低下や薬剤耐性の早期出現を誘 引する可能性が高くなるものと考えられる。したがって， 今後，アルコール摂取時における相互作用の程度を定量的 に把握するための基礎的あるいは臨床的検討がますます重 要となるが, 一方でPI とアルコールの相互作用の可能性 について添付文書などで注意を喚起する必要があろう。ま た，酒類を嗜好する HIV 感染症患者に対する服薬指導と して，治療開始時には飲酒と薬との相互作用とそれに関連 した治療効果についての情報を十分に伝える必要があると 考えられる。

\section{文献}

1) Shibata N, et al. Biopharm Drug Dispos 2003. (in press)

2) Shor-Posner G, et al. AIDS Alert $2001 ; 16: 88-90$.

3) Kresina TF, et al. AIDS Research and Human Retoroviruses $2002 ; \mathbf{1 1}: 757-70$.

4) Lieber CS. Ann Med $1994 ; 26: 325-30$. 